\title{
COMPARISON OF INTRA-ARTICULAR CORTISONE ANALOGUES IN OSTEO-ARTHRITIS OF THE KNEE
}

BY

\author{
M. J. KEHR
}

Charterhouse Rheumatism Clinic, London

The use of intra-articular steroids in the treatment of osteo-arthritis of the knee joints has not been much discussed in the literature. Burgess (1957) states that intra-articular hydrocortone is of most value in joints distended by synovial fluid. Williams (1958) found that hydrocortisone tertiarybutylacetate was effective over a longer period than hydrocortisone, but that both might dramatically relieve symptoms, especially pain, for anything from 2 weeks to several months. Zuckner, Machek, and Ahern (1956) compared the effects of intra-articular hydrocortisone acetate and hydrocortisone tertiarybutylacetate in a number of rheumatic joints, including the knee. They found no significant difference between the two compounds, but stated that 80 per cent. of joints so treated, whether rheumatoid or osteo-arthritic, responded for periods varying from 3 weeks to several months. Hollander and Moore (1956), who studied the intra-articular temperature response to injection of hydrocortisone acetate and prednisone, found that osteo-arthritic joints had a higher temperature than the normal, and that the temperature rose after intra-articular injection. Most of their patients obtained partial or complete relief for a varying period after the injections. Miller, White, and Norton (1958) injected various substances into osteo-arthritic knees, including hydrocortisone, without notable effect.

The purpose of the present investigation is two-fold:

(i) To compare three of these preparations;

(ii) To determine the value of intra-articular steroids in osteo-arthritis of the knees.

\section{Methods}

Twenty patients (ages ranging from 38 to $76 \mathrm{yrs}$ ) suffering from osteo-arthritis of the knees were included in the trial. In nine cases both knees were involved and in the remainder only one knee. Ten patients had some degree of swelling, and movement was much restricted in four.

The clinical diagnosis in each case was confirmed by $x$-ray examination, and rheumatoid arthritis was excluded as far as possible by estimating the erythrocyte sedimentation rate and performing the Rose-Waaler agglutination test in each case. In none was the E.S.R. higher than $12 \mathrm{~mm}$./ hr (Westergren), and the RoseWaaler test was negative in each case.

Three steroids were used:

(i) Hydrocortisone acetate (Efcortelan-Glaxo);

(ii) Prednisolone tertiary-butylacetate (Codelcortone-Merck, Sharp and Dohme);

(iii) Prednisolone trimethylacetate (UltracortenolCiba).

The doses given in each injection were those recommended: $25 \mathrm{mg}$. (1 c.c.) Efcortelan; $20 \mathrm{mg}$. (1 c.c.) Codelcortone; $10 \mathrm{mg}$. (1 c.c.) Ultracortenol. For the purposes of the trial only one injection of each compound was given.

Before the first injection, the degree of movement of the affected joint was roughly assessed, and the joint measured just above the patella to estimate the amount of swelling.

The patient was asked to keep a record of any improvement or otherwise in the degree of pain after the injection. Each patient was seen a week after injection. If there was no significant improvement, a different steroid from that used initially was injected, but if pain was much alleviated no further injection was given until symptoms recurred.

No controls were used, as this trial was primarily intended as a comparison between various types of steroids. The patients were not told which steroid was being administered in a particular injection, and the three compounds were adequately randomized.

No other treatment was given during the trial. 


\section{Results}

The general results are shown in Table I, and a comparison between the three types of steroid is set out in Table $\amalg$ (opposite).

Only three patients failed to derive any benefit from the treatment, and eight obtained relief lasting a month or more. Some of these had had long courses of physiotherapy and/or analgesics before attending the clinic.

An interesting and entirely unexpected feature of the trial was the marked divergence shown by some of the patients in their response to the three types of steroid used:

Case 6, a woman aged 56, and Case 7, a man aged 53, obtained 6 months' freedom from pain after one injection of Codelcortone, but failed to respond to the other steroids.

Case 10, a man aged 67, obtained no relief with Codelcortone, but 4 months' complete relief with Ultracortenol.

Case 11, a woman aged 59, was free from pain for
6 months after an injection of Efcortelan, whereas the $\frac{\mathscr{2}}{3}$ other steroids afforded her no relief at all.

Case 13, a woman aged 57, obtained 3 months' relief $\stackrel{\frac{\infty}{\infty}}{\text {. }}$ after the injection of Ultracortenol, but no relief from $\overrightarrow{\vec{S}^{3}}$ the other steroids.

The degree of swelling was affected as well as

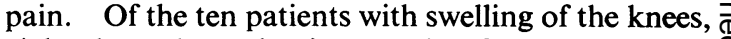
eight showed a reduction ranging from 0.5 to 3 in. Of the four patients who had severe restriction of क movement, two improved considerably, but the $\overrightarrow{0}$ other two were unaffected.

The progress of three typical cases is shown below:

Case 11, a housewife aged 59, had had severe pain in both knees for some months, and experienced great 0 difficulty in getting up and down stairs. On examination $\vec{\infty}$ both knees showed moderately advanced osteo-arthritis without swelling. Analgesics and a long course of $\omega$ physiotherapy had had no effect. After one injection $\mathrm{N}$ of $25 \mathrm{mg}$. Efcortelan into each knee she was completely free from pain for a period of 6 months.

Case 10, a man aged 67, who had suffered from severe pain in his left knee, unrelieved by analgesics, for $2 \mathbb{D}$ months, was completely free from pain after one injection $\overparen{\Phi}$ of Ultracortenol and remains so 4 months later.

TABLE I

KNEE INVOLVEMENT AND RESPONSE IN 20 CASES

\begin{tabular}{|c|c|c|c|c|c|c|}
\hline \multirow{2}{*}{$\begin{array}{l}\text { Case } \\
\text { No. }\end{array}$} & \multirow{2}{*}{ Sex } & \multirow{2}{*}{$\begin{array}{c}\text { Age } \\
(\mathrm{yrs})\end{array}$} & \multicolumn{2}{|c|}{ Knee Involvement } & \multicolumn{2}{|l|}{ Response } \\
\hline & & & Left & Right & Relief of Pain & Swelling \\
\hline 1 & $\mathbf{F}$ & 76 & Severe & Severe & Up to 25 days & None \\
\hline 2 & $\mathbf{F}$ & 73 & Severe & Severe & Some in right knee & +- not reduced \\
\hline 3 & $\mathbf{F}$ & 54 & Severe & Severe & Complete for 4 weeks & Reduced by $\frac{1}{2}$ in. \\
\hline 4 & $\mathbf{F}$ & 38 & Moderate & None & 14 days & None \\
\hline 5 & $\mathbf{M}$ & 67 & Moderate & None & None & None \\
\hline 6 & $\mathbf{F}$ & 56 & None & Moderate & 6 months at least & Reduced by 1 in. \\
\hline 7 & $\mathbf{M}$ & 53 & Moderate & Slight & Right, no pain; Left, some improvement & None \\
\hline 8 & $\mathbf{F}$ & 54 & Moderate & Severe & None & ++ not reduced \\
\hline 9 & $\mathbf{F}$ & 62 & Severe & None & Some relief at first; later no response & Much reduced by at least 3 in. \\
\hline 10 & $\mathbf{M}$ & 67 & None & Moderate & Complete for 4 months & None \\
\hline 11 & $\mathbf{F}$ & 59 & Moderate & Moderate & 6 to 7 months & None \\
\hline 12 & $\mathbf{F}$ & 57 & Severe & None & 30 days & Reduced by $\frac{1}{2}$ in. \\
\hline 13 & $\mathbf{F}$ & 57 & None & Moderate & 3 to 4 months & None \\
\hline 14 & $\mathbf{M}$ & 65 & Moderate & None & None & No response \\
\hline 15 & $\mathbf{M}$ & 63 & Moderate & None & Complete for 6 weeks & None \\
\hline 16 & $\mathbf{F}$ & 57 & Severe & Severe & Slight & Reduced by $\frac{1}{2}$ in. \\
\hline 17 & $\mathbf{M}$ & 63 & Moderate & Nil & Improved for 14 days & Reduced by 1 in. \\
\hline 18 & $\mathbf{F}$ & 68 & Moderate & Moderate & So far 21 days & None \\
\hline 19 & $\mathbf{F}$ & 53 & Moderate & Moderate & Right, 14 days; Left, 21 days & Left reduced by $\frac{1}{2}$ in. \\
\hline 20 & $\mathbf{M}$ & 59 & Severe & Not painful & 4 weeks & Reduced by 1 in. \\
\hline
\end{tabular}


Case 20, a man aged 59, had had 4 months' physiotherapy without effect for advanced osteo-arthritis of the left knee, which was swollen and very painful, and showed gross radiological changes. After one injection of $10 \mathrm{mg}$. Ultracortenol he was entirely free from pain for a period of 4 weeks and the circumference of the knee decreased by 1 in. within a week. He has been kept free from pain by injections of Ultracortenol at intervals of 4 to 6 weeks.

The three patients who did not respond were Cases 5, 8, and 14 . Of these only Case 8 had severe osteo-arthritis with swelling and limitation of movement, and this patient has so far not responded to other medical treatment, including analgesics and physiotherapy. The other two patients had rather mild arthritis, but with limitation of movement in one, and both responded very well to a course of short-wave therapy to the affected knee.

\section{Discussion}

The value of intra-articular steroids in the treatment of osteo-arthritis of the knees has been convincingly demonstrated in the past years at various hospitals and clinics, but the results obtained have not always been published. The author feels that this is the treatment of choice, and superior to analgesics, physiotherapy, and the injection of other compounds into the knees.

It has been widely held that intra-articular steroids are of value only in cases of articular swelling. The results obtained in this series do not entirely support this view; three of the patients who obtained most relief had no joint swelling at any time during their attendance at the clinic.

None of the steroids used was entirely superior to the others, yet in six cases, where two of the three failed, the third proved to be singularly successful. No reason can be advanced for this finding, the active contents of the three compounds being very much alike. Nevertheless, it appears that, if one type of steroid fails, another may succeed.

\section{Summary}

Twenty patients suffering from osteo-arthritis of the knees were given intra-articular injections of

TABLE II

RESPONSE TO INTRA-ARTICULAR STEROIDS IN 20 CASES

\begin{tabular}{|c|c|c|c|}
\hline \multirow{2}{*}{ Case No. } & \multicolumn{3}{|c|}{ Response to Various Steroids } \\
\hline & Efcortelan & Codelcortone & Ultracortenol \\
\hline 1 & Right, 25 days; Left, 18 days & Right, 28 days & Left, 8 days \\
\hline 2 & Right, 7 days; Left, none & None & None \\
\hline 3 & None & 28 days & 14 days \\
\hline 4 & 14 to 21 days & 14 days & Not known \\
\hline 5 & None & None & Slight for 2 to 3 days \\
\hline 6 & None & 6 months & None \\
\hline 7 & None & Right, full relief; Left, some relief & None \\
\hline 8 & None & Right improved at first & None \\
\hline 9 & 28 days & 7 days & 15 days \\
\hline 10 & Not used & None & 4 months \\
\hline 11 & 6 months & Left, 12 days & None \\
\hline 12 & 30 days & 12 days & None \\
\hline 13 & Slight & 14 days & 3 months \\
\hline 14 & None & None & None \\
\hline 15 & 6 days & 6 weeks at least & Not used \\
\hline 16 & None & Slight & None \\
\hline 17 & 14 days & 14 days & Not used \\
\hline 18 & None & None & 21 days \\
\hline 19 & None & Right, 14 days & Left, 21 days \\
\hline 20 & Not used & Not used & 4 weeks \\
\hline
\end{tabular}


three types of steroid. No conclusive evidence was obtained that one type of steroid was superior to the others, but it was shown that if one steroid fails to give relief, it is always worth while trying another.

It is felt that intra-articular steroids should be tried in every case of painful osteo-arthritis of the knee, whether there is swelling or not.

I wish to thank Dr. E. T. D. Fletcher, without whose advice and constant encouragement this paper could not have been written; Dr. H. Coke, pathologist, Charterhouse Rheumatism Clinic, for his valuable help; and the firms of Glaxo, Ciba, and Merck, Sharp, and Dohme who provided materials for the trial.

\section{REFERENCES}

Burgess, T. W. (1957). Med. J. Austr., 2, 816

Hollander, J. L., and Moore, R. (1956). Ann. rheum. Dis., 15, 320.

Miller, J. H., White, J., and Norton, T. H. (1958). J. Bone Jt Surg. $40 \mathrm{~B}, 636$.

Williams, G. T. (1958). J. Louisiana med. Soc., 110, 124.

Zuckner, J., Machek, O., and Ahern, A. M. (1956). Ann. rheum. Dis., 15, 258 .
Comparaison des analoguës de la cortisone par voie intra-articulaire dans l'ostéo-arthrite du genou

\section{RÉSUMÉ}

Vingt malades atteints d'ostéo-arthrite des genoux $\vec{\equiv}$ reçurent des injections intra-articulaires de trois types $\stackrel{?}{\hookrightarrow}$ de stéroïde. On n'obtint pas de preuve concluante qu'uno type de stéroïde soit supérieur à un autre, mais on démontra que lorsqu'un stéroïde échoue, il vaut bien $\overline{\bar{s}}$ en essayer un autre.

On croit que l'injection intra-articulaire d'un stéroïdeڤ doit être essayée dans tous les cas d'ostéo-arthriteôn douloureuse du genou, tant en présence qu'en absence d'une tuméfaction.

Comparación de análogos de la cortisona intra-articular en la ósteoartritis de la rodilla

\section{Sumario}

Veinte enfermos con ósteoartritis de la rodilla recibieron inyecciones intra-articulares de tres tipos deco esteroides. No se obtuvo prueba conclusiva de que unt tipo de esteroide sea superior a otro, pero se comprobów que al fallar uno, vale la pena ensayar un otro.

Se cree que una inyección intra-articular de un esteroideo debe usarse en todos los casos de ósteoartritis dolorosa de la rodilla, con o sin hinchazón. 